\title{
Perspectives, politics and prospects to combat the Coronavirus
}

\author{
Amrita Panja \\ Research Scholar, Molecular Biology and Human Genetics Laboratory, Department of Zoology, The University of \\ Burdwan, West Bengal, India
}

The Coronavirus disease (Covid-19) pandemic emerged in Wuhan, China during December 2019 and has spread all over the world. It has brought about huge threats to health and lives. The virus is highly contagious and it continuously evolves in the human population. The article is aimed to analyse the perspective, politics and probable prospects of Covid-19. It is further focused on possible challenges during the pandemic situation. Intensive research required in the field of virology to identify the probable potential drug invention for developing treatment strategies. This pandemic causes emotional, economic and social problems. Although the pandemic has some positive effects also. The article emphasizes the political and sociological aspects of the pandemic situation. Under the crisis, people have realised the value of caring, sharing, loving and helping the distressed ones instead of luxurious lifestyle. The pandemic has surely led to a new normal in our lives.

Key words: Coronavirus disease (Covid-19); perspective; politics; pandemic; new normal life

\section{Access this article online}

Website:

http://nepjol.info/index.php/AJMS DOI: 10.3126/ajms.v12i2.31869

E-ISSN: 2091-0576

P-ISSN: 2467-9100

Copyright (c) 2021 Asian Journal of Medical Sciences

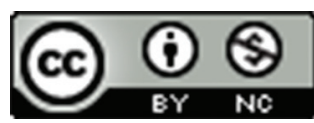

This work is licensed under a Creative Commons Attribution-NonCommercial 4.0 International License.

\section{INTRODUCTION}

In the world, the major changes normally happen according to geological time scale; but the robust alterations brought about by Covid-19, in 2020 is notable. Currently, people all over the world are suffering from Coronavirus disease (Covid-19) and it is the fifth pandemic after the flu pandemic of 1918. ${ }^{1}$ It becomes a major global health challenge and most of the countries faced a significant crisis in health, politics and economic field. It is a highly transmissible disease caused by severe acute respiratory coronavirus 2 (SARS-CoV-2) spreading among the human community at an alarming rate. It is emerged at first in Wuhan, China at the beginning of December 2019 and then after it started to spread throughout different countries in very expeditious rate which is even beyond anyone's far imagination. In the present scenario, the Coronavirus appears as a global threatening agent to the human society. ${ }^{2}$ Unfortunately, many countries have not followed the proper guideline provided by WHO. It is instructed by the health caring organiser to perform more testing so that the possibility of mass transmission can be ruled out. Globally, as of $1^{\text {st }}$ October 2020, there have been 33,722,075 confirmed cases of Covid-19, including 1,009,270 deaths, reported to $\mathrm{WHO}^{3}$

Looking back to the start of 2020, the whole world has been changed so drastically that it is almost beyond recognition. The global economy has been come at the edge of great loss to protect public health. Shops are remaining closed, production from most of the factories are mothballed, general people are facing mental distress and panic as the lockdown phase has prevailed everywhere and nobody knows where the end is. The Covid-19 pandemic illuminates the role of politics, economics and other circumstances related to the future aspects. Public health 
experts warned before, the policymaker to be prepared for the pandemic situation. ${ }^{4}$ Although, they even have never thought about spending money and time in research and health system. Therefore, presently people have to tolerate the devastating phase of the pandemic, as most of the countries are unaware of the probable situation.

Microbes do not understand the boundaries between poor and rich as well as boundaries between countries. The lack of communication has made the situation worst ever and general people are suffering the most. Therefore, at present, global response from everywhere is required for combating the situation. A coordinated international response can be the best way to confront the pandemic situation. World Health Organisation (WHO) attempt to coordinate between different countries during the time of crisis but they are helpless as potential political leaders oppose. The pandemic situation leads a great challenge to be faced by the political leaders and it is the time to take advantage of the opportunities as well as lesson to build a better world. The crisis generated by Corona pandemic is a once-in-a-generation global turning point when many of the primary aspects of our social and economic life will be remade and a 'New Normal' established. ${ }^{5}$ With Covid-19, nature is sending us a message that we need to recognize the interrelationship between animals, including pets, livestock and wildlife and improve hygienic practices.

\section{EMERGENCE OF NOVEL CORONAVIRUS (2019-nCoV)}

Coronaviruses are known for severe respiratory infection, fever, tiredness, cough, chest pain along with some mild and severe clinical manifestations. In most cases, the signs and symptoms are visible within 4 to 6 days after being exposed to the virus. Previously, Coronavirus infection was also reported from several veterinary species like camels, rodents, cats, dogs, bats and avian species. ${ }^{6,7}$ Corona infection was first time described in the year of 1960 in human. Although, it took everybody's attention during 2002-2003 when severe acute respiratory syndrome suddenly emerged out. ${ }^{8,9}$ Following the occurrence of SARS-CoV; another strain of CoV known as HKU3-1 to HKU3-3 was successively identified in the horse-shoe bats. ${ }^{10}$ Therefore, generally people use to believe that probably bats are the natural host and potential reservoir species for CoVs epidemics. In around 2012, another similar CoVs was outbroken worldwide known as MERS$\mathrm{CoV}$ (Middle East Respiratory Syndrome). ${ }^{11}$ This time, again the origin was tracked from bats. Unlike SARS and MERS-CoVs, this virus has a relatively mild symptom with a low mortality rate. But novel Coronavirus has a high risk of human to human transmission.
Few cases of pneumonia with respiratory trouble were appeared first from the Wuhan city of Hubei province of China since late December, 2019. ${ }^{1}$ After critical intervention into this matter, it was notably found that the patients had a history of visiting nearby seafood market in Huanan. Possibly this seafood market is the place of zoonotic (animal to human) transmission by which the coronavirus has been emerged out. On $7^{\text {th }}$ January, 2020 China Centre for Disease Control and Prevention (CDC) revealed that a new strain of Corona virus has been appeared as novel Coronavirus ( $\mathrm{nCoV}$ ). Realising the pathogenicity of this novel virus that causes global threat, World Health Organisation (WHO) declared it as a 'Public Health Emergency of International Concern' on January $30^{\text {th }}, 2020 .{ }^{12}$ The Director- general of WHO, Dr. Tedros Adhanom Ghebreyesus, announced this unknown diseasecausing pneumonia like syndrome as 'Covid-19'. After that, on $11^{\text {th }}$ March WHO declared Covid-19 as 'pandemic'. ${ }^{13,14}$

\section{PERSPECTIVE OF CORONA PANDEMIC}

Covid-19 has badly affected our daily lifestyle and it gradually slows down the global economy. Thousands of people are now victimised and many of them are being killed. Human civilization is under threat of this pandemic. It rapidly diminishes the progressive movement towards business, education and culture. Despite many adverse effects of this pandemic, there is some positive ray of hope that makes the circumstance a little better.

\section{Positive effects}

1. Due to the lockdown phase during Corona pandemic, lakhs of liters of fuel (Petrol/Diesel) have been saved as most of the time we are confined in our home and there is a restriction for riding outside.

2. The skies seem clearer than before due to reduced generation of air pollutants.

3. People get to spend time with family members and can plan for future work better.

4. During the pandemic, most of the people have slept a few extra hours and woke up without worrying about tensions and anxiety of busy schedules.

5. People learn to practice better Hygiene. It is not only a good habit but also a great way to live long and survive in a healthier way.

6. This quarantine period welcomes new ideas, innovations, tips and tricks to beat the agony of the lockdowns and serve the communities to a better future.

7. Discoveries and researches can be explored during the lockdown phase.

8. People remember to cover mouths when cough, to sanitize hands after touching anything else.

Asian Journal of Medical Sciences | Feb 2021 | Vol 12 | Issue 2 
Unknowingly, we can decrease the burden of some airborne diseases like tuberculosis, food/water- borne diseases like diarrhea, cholera etc.

9. Online classes have become the new norm for educational institutions and it has come with a few benefits too. Institutions can now save on the infrastructural costs and as a result, the students needn't bear the brunt of the costs, making it more affordable. Apart from that, parents can get unique opportunities to know about how online classes are taught and can better understand the learning capability of their children.

10. People have developed a habit of keeping a check on the latest news and staying updated with the world.

11. People have adapted many new habits like practicing 'namaste' instead of shaking hands. The mode of lifestyle has been changed drastically and all the changes motivate us towards the new normal life.

\section{Negative effects}

The negative impact of Covid-19 includes illness, mortality, lockdown phase, isolation, curfew and unexplained mental harassment and trauma. ${ }^{15}$ In this article few negative effects of Covid-19 which are coming from local, regional and community level of a nation has been discussed as follows:

A. Social behaviour: Human behaviour will be affected due to long periods of isolation and danger caused by the pandemic.

1. According to Scientists, due to the prolonged lockdown phase, the ability to focus, to feel easy and comfortable around others, even to think more than a few days into the future, may reduce.

2. Large gatherings are strictly prohibited during the pandemic situation. Many social and cultural programs like weddings, sporting events or concerts would be ruled out. Malls, gyms, restaurants, bars and places of worship are temporarily closed.

3. People may struggle to regulate their emotions, finding anger and panic come more easily.

4. During the pandemic situation, many people are suffering from insomnia and substance abuse.

5. People have to keep social distancing with their peers and family members.

6. Important examinations are postponed and students are facing trouble.

7. Although the online education system has been commenced on. There is a huge gap in the proper supply of internet system especially in urban and rural areas. The virtual class lacks the irreversible communication between teacher and student.

8. The family relationship with relatives, friends, neighbours and various communities is dismantling. The communication gap between close relatives may lead to interpersonal conflicts and domestic violence in the family.

9. There is a gradual decline in religious belief systems. General people may not believe in superstitious powers, in God Almighty and other heavenly and supernatural elements in society.

B. Healthcare: The biomedical systems, have taken their maximum exertion for combating the pandemic situation.

1. Overload on doctors and other healthcare professionals, health staffs, who are at very high risk.

2. Overload on medical shops.

3. Patients with other diseases and health problems are getting neglected and are being the worst sufferer.

C. Economic: Global Economic recession prevails and poverty level in society increases day by day. This may lead to financial crises such as a decline in monetary values, share market values and businesses. Slowing of the manufacturing of essential goods.

1. Disrupt the supply chain of products

2. Losses in national and international business

3. Poor cash flow in the market

4. Significant slowing down in the revenue growth.

5. Many people are losing their jobs in the government and private sectors.

6. Several lower hierarchy social classes facing an intolerable economic crisis due to lack of daily or monthly salaries and all these situations lead to downward the family economic condition.

\section{MYTHS RELATED TO THE PANDEMIC}

The people of the Indian subcontinent are simple and believe in different superstition and myths. Myths may be social, political, religious and economic. Some of them may have little reality but most of them have no supportive shreds of evidences.Many people believe that Corona pandemic is the curse or punishment of God. Some people believe that Chinese people use to eat many types of insects, frogs, monkeys without properly cooking. Scientific studies revealed that every organism contains many types of bacteria, viruses and when human consume these biological things, microorganisms use to enter inside the body and lead to form pathological effects. Due to the robust industrial development, humans are increasing their exposure to wild animals. It increases the chance of zoonotic infection in human. Deforestation leads to degrading the wildlife natural habitat and they become more stressed and causing transmission of diseases between human and wildlife. Muslim community believe that the coronavirus is a matter of Halal or Haram; although it has no strong 
scientific evidence. Many Christian people believe that the coronavirus occurs due to the evil behaviour of human. ${ }^{16}$ Under the pandemic situation, many people assume that the coronavirus is the result of the biological weapon invented in Wuhan's Laboratory, China.

\section{POLITICS ASSOCIATED WITH CORONA PANDEMIC}

Covid-19 pandemic not only infects people all over the world but also influences health care facilities, lifestyles, social dimensions as well as Governments approach towards directing the Nation. The correlation between people's psychology and Government's policy is very important to come over the crisis during the pandemic situation. ${ }^{17}$ Responding and taking probable actions for combating the pandemic situation is always a political act. Determination of the duration of lockdown phase, the degree of quarantining people, health information to general people of the Nation and making common people aware about the pandemic are some of the crucial steps from the leader of any Nation. ${ }^{18}$ Research agenda to study the involvement of politics is the foremost important topics in the present scenario. It will open the probable gateway for developing more realistic interventions in policies to shape the problems arise in the public health system during the crisis.

\section{Gender politics during the corona pandemic}

Voters usually prefer male leaders due to male dominance in society. Thus, the female political leaders are often neglected and underestimated. However, it has been long been argued whether corona pandemic has opened up opportunities for the feminine traits in the political sector. It is the general concept prevailed in our society that male political leader protects the nation by their strong musculature. Coronavirus has an impact on sexual biasness and it allows to accept the power of protective femininity over masculinity for the purpose to ensure the security of the citizens. ${ }^{19}$

\section{Politics in administrative level}

Governments all over the world often maintain secrecy and being reluctant to share the real news of morbidity of this pandemic nationwide. Gradually, the state of emergency becomes the 'new norm'. The present time is extraordinarily important as it really and logistically requires recalibration in the relationship between the executive and legislature. During the crisis period, the political leaders, medical governing bodies, national and international executives have scrambled to manage the proper control of data and figure. Ruling bodies try to exhibit the 'flattened curve' of the pandemic and take support from the general population of the country. The social strategy taken by the political leaders might make people anxious and frightened. In many cases, extreme restriction for isolation seems to be unpleasant.

\section{NEW NORMAL LIFESTYLE}

During the pandemic situation, people must learn to deal with the mysterious microbe that causes disaster to the modern lifestyle. In many aspects, life will return to a resemblance of the past after this tragic episode; but in more areas than one might expect, life will never be the same. Amid during pain and despair they bring about new thinking, ideas and frequently accelerate much needed reform-"The New Normal Life".

\section{Prospective towards new normal lifestyle}

1) Covid-19 will accelerate high speed digital technology, which help to connect with educational institutes (Schools, Colleges, Universities), doctors, shops and even the gyms.

2) Trade, business and industry have been impacted in equal measure, although agriculture seems to have shown some suppleness to beat the adverse effects of the virus.

3) Avoidance of non-essential travel and luxurious spending.

4) Maintenance of social distancing, isolation, hand hygiene (by washing hands more frequently with effective hand sanitizer or hand wash), and the wearing of the protective mask.

5) There is significant decline in avoidable lavish spending on social occasions such as marriages and other such communal celebrations.

6) The pandemic has surely guided towards a 'new normal' mode of lifestyle. It may sometimes appear to be illogical and restraining, but is not reprehensible or problematic. In many ways, 'new normal' lifestyle taught us discipline, care for one another, use of technology, financial responsibility, and prudence in life.

7) Many industries being brought back into national infrastructures.

8) People have to accept that millions will get infected in future and one reliable vaccine can stop the track. Therefore, mental strengthening is an important approach for adjusting with the new normal.

9) There is a huge loss in global and national economy during the lockdown phase.

\section{COMBATING CORONA}

Combating corona is a major challenge in the present scenario.Various factors influence for achieving the 
flattening of the epidemiological curve. Following strategies can be followed for combating Corona pandemic:

1. Quarantine of all contacts: Quarantining is the most effective way for battling against Corona Pandemic. Aggressive and strict strategy should be taken by the administrative leaders for quarantining the people arriving from hotspots areas. At least 3-4 weeks quarantine or social isolation should be followed for immigrant people and corona testing must be done if any clinical symptoms found. The people with corona positive result should be shifted to specific hospitals with extreme care. All the primary and secondary contact people should be instructed to follow the social distancing. ${ }^{20}$

2. Improvement of Healthcare system: Sufficient number of Covid-19 special hospitals with all required infrastructure facility should be undertaken and functional. Apart from Government hospitals, various private hospitals with critical care unit should be managed. Sufficient Doctors, health workers, trained nurses must be available in health care sectors.

3. Testing of suspected cases: Screeningof the suspected cases is the foremost important step that can stop spreading of this epidemic. The greater number of the screening test can identify the asymptomatic patients and thus, prevent the chance of mass transmission.

4. Break the chain campaign: Frequent hand washing, sanitization, maintaining social distancing and wearing protective masks are some of the effective management strategies for combating Corona. Local administrative leaders should be more active to make sure that people in their area abide by these rules and regulations.

5. Improving internet connection: During the lockdown phase, most of the people are asked to work from home, especially in the Information Technology (IT) sector and online education system.

6. Community Kitchens: The idea behind the community kitchen is that no one should be left without food in any province of a country during the lockdown phase. In developing and low-income countries, there is a considerable number of guest workers and labours who face terrible economic situation during the pandemic. Since these people have no work and most of the restaurants remain closed, it is essential to start the community kitchen for ensuring no people would be suffering from hunger.

\section{FUTURE PROSPECTIVE AND POSSIBLE REMEDIES}

Scientists from China recently successfully isolated the 2019-nCoV virus strain. On other hand, scientists from
Melbourne, Australia successfully now able to culture Wuhan Coronvirus cell culture. Many types of research are going on for establishing the replication, transcription and translation of Covid-19 virus in the human body. It can be anticipated that ongoing researches can be able to discover effective therapeutics as well as vaccine. The discovery of vaccine is greatly limited due to the extensive diversity in antigenic variants. ${ }^{21}$ Therefore, it will take a considerable time for inventing effective and successful vaccine; but till then, we need to rely on strict lifestyle including social distancing and lockdown to minimize the transmission. ${ }^{22}$ According to Cohen, 2020, the combination therapy with monoclonal antibody and Remdesivir drug can be a probable therapeutic option. ${ }^{23}$ Scientists of different countries coming from all over the world are now tackling hard to discover potential therapeutic. Although we have to keep patience till these therapies are tested as safe, potential and effective. ${ }^{21,24,25}$

Many apocalyptic predictions have been made about the situation made after the post-Covid-19 world. The appearance of Covid-19 act as a morning wake up bell for all the individuals of society and in a country. Life after the corona pandemic should not be the same and it will call for a significant change in the field of development and priorities. Different virus-related pandemic has been outbroken previously like SARS, MARS, Ebola, Zika, Nipah etc. which are the warning bells for us. Moreover, many bacterial diseases are also found which are potent enough to be life-threatening and many of them acquire natural resistance power against conventional antibacterial drugs. All these indicate that more investment should be given to the researches related to infectious diseases. Unfortunately, after the discovery of antibiotics in 1940s-50s, researches in the field of infectious diseases started losing their importance. In a post-Covid-19 world, pandemic-focused researches should be started with topmost priority.

Most interestingly, the prevalence of Covid-19 is not so significant in Africa and South America which indicates that respiratory viruses are more virulent in Winter climatic condition. There is also a significant cultural difference in different countries according to the prevailing climatic condition. Immunological differences (innate immunity), pre-exposure to coronaviruses, temperature difference, exposure to sun rays (UV light exposure due to spending more time outdoor than indoor) and genetic constituents (including SNPs, VNTRs) play important role in the differential mortality rate and affected rate among different countries. Therefore, the factors which influence the survival capacity of the virus can give hopeful direction for the prevention of this pandemic. ${ }^{26-28}$ 


\section{CONCLUSION}

Covid-19 is the most recently emerged virus throughout the world after the phobia caused by Ebola, Nipah and Zica like viruses. ${ }^{29}$ The crisis can reorganize the world in dramatic ways for better or worse condition. The pandemic situation has taught us how to survive with the odds. People must reconsider their lifestyle and that may rediscover better version of ourselves. It may encourage the rising of some human good attitudes like empathy, humanity, kindness, caring, sharing, loving and generosity of spirit. All these nice qualities may improve the hostile condition of the world. Covid-19 has become a panic for human communities and it threatens every sphere of the society. Although the sharing of reliable scientific information and knowledge can reduce conspiracy and psychological burden. Mutual respect, trust, confidence and global cooperation are some of the important ways to cope up the situation of crisis. ${ }^{30,31}$ The pandemic situation explores an opportunity for rethinking and rediscovering us and to select the pathway of benevolence. ${ }^{32}$ Covid-19 is a wakeup call for making a society where harmony and empathy prevail, good opportunity for scientific education and better international correlation. We cannot turn back the Covid-19 clock as before but we can learn valuable lesson from the catastrophic situation caused by the pandemic. Due to Covid-19 pandemic, nature gives the opportunity to build the world greener, smarter and fairer.

\section{REFERENCES}

1. Liu YC, Kuo RL and Shih SR. COVID-19: The first documented coronavirus pandemic in history. Biomed J. 2020; S23194170(20):30044-30045

https://doi.org/10.1016/j.bj.2020.04.007

2. Jakovljevic $M$, Bjedov $S$, Jaksic $N$ andJakovljevic I. COVID-19 Pandemia and Public and Global Mental Health from the Perspective of Global Health Securit. PsychiatrDanub.2020;32(1):6-14.

https://doi.org/10.24869/psyd.2020.6

3. WHO Coronavirus Disease (COVID-19) Dashboard [Data last updated: 2020/10/1, 10:45am CEST]. Available from: https:// covid19.who.int/coronavirus/dashboard

4. Kamradt-Scott A. Changing perceptions: of pandemic influenza and public health responses. Am J Public Health. 2012;102(1):90-8. https://doi.org/10.2105/AJPH.2011.300330

5. Dobson J. Covid-19 is accelerating the New Normal. Sunday Guardian Live [cited on May23,2020]. Available from: https:// www.sundayguardianlive.com/news/covid-19-accelerating-newnormal.

6. Fehr AR and Perlman S. Coronaviruses: an overview of their replication and pathogenesis. Methods Mol Biol. 2015;1282: $1-23$.

https://doi.org/10.1007/978-1-4939-2438-7_1

7. Kahn JS and McIntosh K. History and recent advances in coronavirus discovery. Pediatr Infect Dis J. 2005;24(Supplement): S223-S227. https://doi.org/10.1097/01.inf.0000188166.17324.60

8. Drosten C, Gunther S, Preiser W, van der Werf S, Brodt H-R, Becker $\mathrm{S}$, et al. Identification of a novel coronavirus in patients with severe acute respiratory syndrome. N Engl J Med. 2003;348(20):1967-1976.

https://doi.org/10.1056/NEJMoa030747

9. Peiris JSM, Lai ST, Poon LLM, Guan Y, Yam LYC, Lim W, et al. Coronavirus as a possible cause of severe acute respiratory syndrome. The Lancet. 2003;361(9366):1319-1325.

https://doi.org/10.1016/S0140-6736(03)13077-2

10. Lau SK, Woo PC, Li KS, Huang Y, Tsoi H-W, Wong BH, et al. Severe acute respiratory syndrome coronaviruslike virus in Chinese horseshoe bats. Proc Natl Acad Sci. 2005;102(39):14040-14045.

https://doi.org/10.1073/pnas.0506735102

11. Zaki AM, Van Boheemen S, Bestebroer TM, Osterhaus AD andFouchier RA. Isolation of a novel coronavirus from a man with pneumonia in Saudi Arabia. N Engl J Med. 2012;367(19):18141820.

https://doi.org/10.1056/NEJMoa1211721

12. Malik YS, Sircar S, Bhat S, Sharun K, Dhama K, Dadar M, et al. Emerging novel coronavirus (2019-nCoV)-current scenario, evolutionary perspective based on genome analysis and recent developments. Vet Q. 2020;40(1):68-76.

https://doi.org/10.1080/01652176.2020.1727993

13. DiGennaro F, Pizzol D, Marotta C, Antunes M, Racalbuto V, Veronese N, et al. Coronavirus Diseases (COVID-19) Current Status and Future Perspectives: A Narrative Review. Int J Environ Res Public Health. 2020;17(8):2690. https://doi.org/10.3390/ijerph17082690

14. WHO Director-General's opening remarks at the media briefing on COVID-19. Cited on March 11, 2020. Available from: https://www.who.int/dg/speeches/detail/who-director-generals-opening-remarks-at-the-media-briefing-on-covid-19---11march-2020

15. Karunathilake K. Positive and negative impacts of COVID-19, an analysis with special reference to challenges on the supply chain in South Asian countries. J Soc Econ Dev. 2020:1-14. https://doi.org/10.1007/s40847-020-00107-z

16. Harrell D. Is the Coronavirus Evil? Or is this part of life in the world God made? Christianity Today, April 15, 2020. Available from: https://www.christianitytoday.com/ct/2020/march-webonly/coronavirus-evil-covid-19-disease theology.html

17. Daniel L. The Coronavirus Crisis. Governance, Social and Political Economy Issues (A Short Note). Ann Soc Sci Manage Stud. 2020; 5(2):555660.

18. Dodds K, Broto VC, Detterbeck K, Jones M, Mamadouh V, Ramutsindela M, et al. The COVID-19 pandemic: territorial, political and governance dimensions of the crisis. Territory, Politics, Governance. 2020;8(3):289-298. https://doi.org/10.1080/21622671.2020.1771022

19. Kathleen D and Lynch T. The Impact of Gender Stereotypes on Voting for Women Candidates by Level and Type of Office. Politics \& Gender. 2016;12(3):573-595. https://doi.org/10.1017/S1743923X16000246

20. Thankappan KR. Combating corona virus disease 2019 and comorbidities: The Kerala experience for the first 100 days. 2020;5(2):36-42. https://doi.org/10.4103/jncd.jncd_26_20

21. Malik YS, Sircar S, Bhat S, Sharun K, Dhama K, Dadar M, et al. Emerging novel coronavirus (2019-nCoV)-current scenario, evolutionary perspective based on genome analysis and recent developments. Vet Q. 2020;40(1):68-76. 
https://doi.org/10.1080/01652176.2020.1727993

22. Cheng VCC, Wong SC, To KKW, Ho PL and Yuen KY Preparedness and proactive infection control measures against the emerging novel coronavirus in China. J Hosp Infect. 2020;104(3):254-255

https://doi.org/10.1016/j.jhin.2020.01.010

23. Cohen J. New coronavirus threat galvanizes scientists. Science.2020;367(6477):492-493.

https://doi.org/10.1126/science.367.6477.492

24. Cyranoski D. This scientist hopes to test coronavirus drugs on animals in locked-down Wuhan. Nature. 2020;577(7792):607. https://doi.org/10.1038/d41586-020-00190-6

25. Zaher $\mathrm{NH}$, Mostafa $\mathrm{MI}$ andAltaherAY. Design, synthesis and molecular docking of novel triazole derivatives as potential CoV helicase inhibitors. Acta Pharmaceutica. 2020;70(2):145-159. https://doi.org/10.2478/acph-2020-0024

26. Hopman J, Allegranzi B andMehtar S. Managing COVID-19 in Lowand Middle-Income Countries. JAMA. 2020;323(16):1549-1550. https://doi.org/10.1001/jama.2020.4169

27. Chin AWH, Chu JTS, Perera MRA, Hui KPY, Yen HL, Chan MCW, et al. Stability of SARS-CoV-2 in different environmental conditions. Lancet Microbe. 2020 ;1(1): e10.

https://doi.org/10.1016/S2666-5247(20)30003-3

28. El Bcheraoui C, Mimche H, Miangotar Y, Krish VS, Ziegeweid F, Krohn KJ, et al. Burden of disease in francophone Africa, 19902017: a systematic analysis for the Global Burden of Disease Study 2017. Lancet Glob Health. 2020;8(3): e341-e351. https://doi.org/10.1016/S2214-109X(20)30024-3

29. Cui J, Li F and Shi Z-L. Origin and evolution of pathogenic coronaviruses. Nat Rev Microbiol. 2019;17(3):181-192. https://doi.org/10.1038/s41579-018-0118-9

30. Harari $\mathrm{YN}$. In the battle against coronavirus, humanity lacks leadership. Time, March 15, 2020a. Available from: https://time. com/5803225/yuval-noah-harari-coronavirus-humanity-leadership/

31. Harari YN. The world after coronavirus. Financial Times, March 20, 2020b. Available from: https://www.ft.com/content/19d903086858-11ea-a3c9-1fe6fedcca75

32. Jakovljevic $M$ andJakovljevic I. Theoretical Psychiatry as a Link between Academic and Clinical Psychiatry. U Kim YK (ur): Frontiers in Psychiatry - Artificial Intelligence, Precision Medicine, and Other Paradigm Shifts. Springer Nature Singapore Pte Ltd. 2019:355-398. https://doi.org/10.1007/978-981-32-9721-0_19

\section{Author's Contribution:}

AP - Conceived the idea, review of literature, drafted the manuscript, critically revised, and approved the final version before submission. Author have read and agreed to the published version of the manuscript.

Work Attributed to:

Molecular Biology and Human Genetics Laboratory, Department of Zoology, The University of Burdwan, West Bengal, India.

Orcid ID:

Dr. Amrita Panja - (1) https://orcid.org/0000-0002-2857-1062

Source of Funding: None, Conflict of Interest: None. 